\title{
PARTICIPATION OF WOMEN IN THE CONDUCT OF \\ COMPANIES
}

\section{Prof. Ass. Drita KRASNIQI}

Prizren University “UKSHIN HOTI, Faculty of Economics, drita.krasniqi@ uni-prizren.com

\section{Article history}

Accepted 15 March 2019

Available online 30 April 2019

Keywords:

Economic,

Management,

Businesses,

Structure of SME,

Developmet.

\begin{abstract}
A b s t r a c t
The structure of the business owners who own firms is an important indicator and gender is treated in terms of business founders, their age group and level of education and professional training for business management. In any economy with market gender structure of owners of firms in business is analyzed and treated with the utmost care, with the aim in this field are performed equal gender rights and to support equal access to opportunities for establishing new businesses Gender structure of the owners of enterprises is an important element in analyzing and monitoring the activities of enterprises. Although in our country women's participation in the leadership of enterprises its small, in recent years has been seen an increase of female participation in the registration of enterprises.
\end{abstract}

The purpose of this research is to produce results relevant to the current situation, structure, problems, difficulties, and to measure the trend of development of micro, small and medium enterprises, to determine the criteria and advanced recommendations for the possibility of supporting the development of them. Analysis of obstacles and difficulties for business development including: a lack of qualified staff, lack of training in various areas, the lack of market, using modern equipment, workspace, physical infrastructure, transportation, finance, legal, economic and fiscal policies, offer the possibility of analysis, creation and research methods and methodologies to support small enterprises and medium enterprises in our country.

\section{Introduction}

The paper is based on official statistical data provided by the institutions that have the responsibility to have them. For evidence that the government itself and the institutions of Kosovo have a short history, still has statistical data are not consolidated.

Chat SMEs have a bearing far too substantial say in the growth of employment in certain countries. It is considered that about $60-70 \%$ of new labor countries of the more developed countries in the world membership, achieved as a result of past employment of peoples in SMEs.

Gender structure of owners of enterprises is an important element in analyzing and monitoring the activities of enterprises. Although in our country women's participation in the leadership of enterprises is small, vitetve recently seen an increase of female participation in the registration of enterprises.

We made paper highlights the obstacles and the difficulties in developing businesses such as lower education, training tracking, application technology an important indicator to assess the activities tëndërmarrjeve etc. activities.

The following is a report of employment of women relative to men by age group, based on statistical data. Yes persevere with particular importance of women participation in leading businesses to lodge formal 
Difficulties and obstacles to women's involvement in the economy.

\section{Gender structure of the founders of enterprises}

The following will make a parqitje participation of women in leadership research report by the competent organs. Greenhaus \& Beutell (1985) to be followed by Female owned firms tend to be of small size, with limited prospects of growth and profitability, and may have problems in finding collateral in order to gain finance from a bank or other source.

Thus, according to SME research from the ministry of commerce and industry of 2005 stream that $98 \%$ of owners of firms in small and medium enterprises are male, while only $2 \%$ are women. A structure of approximately the same gender was characteristic for 2003 and 2004, which shows that women in Kosovo still reluctant to establish businesses on their behalf, either because of lack of economic and financial conditions, either because of insecurity for an entrepreneur.

One of the most important improvements in terms of decision-making positions has been done in politics field, by enabling women to be elected as congresswoman with electoral gender quota. It is important to mention that the gender quota is set at 30 percent in Kosovo (Law No. 03/L-073, Article 27, Paragraph 1., 2008).

In the table are presented data on the participation and role of women in the ownership of companies, which also has a positive effect on economic development. In the table are presented data of enterprises by female ownership at the country level.

Table 1. SMEs by a gender structure

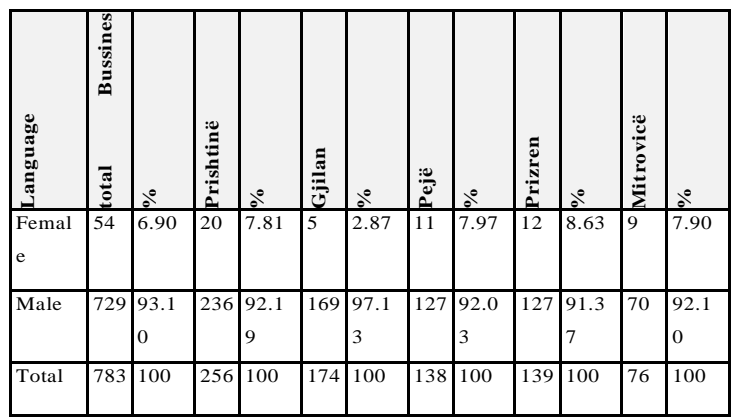

Source: Ministria e Tregëtisë dhe Industrisë Rapor, 2011 Hulumtimi i 800 Ndërmarrjeve të Vogëla dhe të Mesme, Prishtinë pp.10

From the table we can see that the increased participation of females in the establishment of business is in the region of Prizren $8.63 \%$, Peja region $7.97 \%$, Mitrovica region $7.90 \%$, followed by Pristina region $7.81 \%$ and the share of small women in the establishment of Business is in Gjilan region with $2.87 \%$.

While most large participation of men in setting up businesses is in Gjilan region with $97.13 \%, 92.19 \%$ region of Pristina, Mitrovica region $92.10 \%$, then 92.03\% regjini Peja and Prizren region with $91.37 \%$.

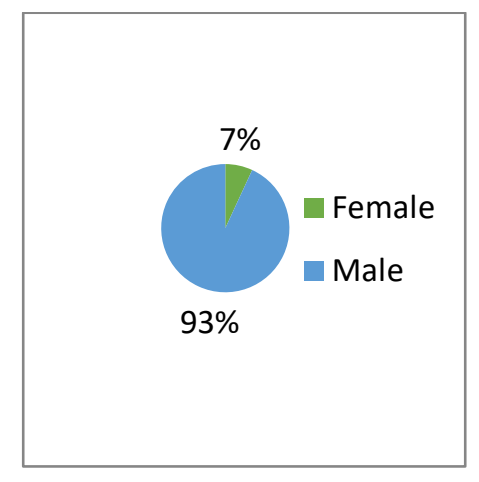

Figure 1. SME structure by gender

From the chart we can see that women's participation in the ownership of enterprises is about $7 \%$. Surveyed enterprises out of 729 (93\%) of them are owned by men.

\section{Analysis of obstacles and difficulties for business development}

The data in the report of the survey of SMEs note that the total number of employees without school and elementary school does not exceed only $15.5 \%$ of females and $85.4 \%$ males, the structure of employees in preparation educational secondary school is participating around $24 \%$ female and $76 \%$ male, with high school $24.5 \%$ female, $76 \%$ male. While the educational preparation of college employees $19.1 \%$ female and $80.9 \%$ male, then the employees with master's degree $28.8 \%$ female and $71.2 \%$ male. Structure of employees by gender $\mathrm{PhD}$ noun gjithëashtu dominated by $83.3 \%$, while the female population $16.7 \%$.

The rapid development of information technology, radical economic changes and dynamic market, 
impose permanent monitoring of changes and learning countinual. A proven form of human capacity building within the enterprise are training. Although smallscale monitoring of such training has begun applied to enterprises in Kosovo. Of all the firms surveyed have $25.42 \%$ of them stated that they have continued training in the past three years, while $74.58 \%$ of them stated that they have conducted trainings. Training course have their financial cost and it is not easy to part of the SME-s to participate in these trainings.

Follow the trend of development of advanced methodologies and application of modern technology is an important indicator to assess the activities of the activities of enterprises, as well as to determine the level of development of modern enterprises. Besides there are also difficulties incidental in the workspace, physical infrastructure, transportation and finance.

\section{The number of women's business owners}

In Kosovo, women are still hard assets as an entrepreneur - at least in formal terms. Businesses owned by women are rare. According to the data, in general, only $13 \%$ of SMEs are owned by women and another $3 \%$ are co-owned by women. So, the remaining $84 \%$ of SMEs are owned by men. However, the incidence of female entrepreneurship is higher in personal and business services, where $23 \%$ and $35 \%$ of companies, respectively, are controlled by women. In other sectors, the proportion of women is much lower; building in particular has practically owned by women in all businesses. Moreover, women are mainly active business as solo-entrepreneurs, while the larger category size women become more rare. Finally, there are relatively more female entrepreneurs in the Pristina region ( $18 \%$ plus $6 \%$ co-ownership) than in other regions (10\% plus $2 \%$ co-ownership on average). companies led by women - average - a bit younger than those men-led, which means that self-employment is an option of last career for women. (Oberholzner, 2014, p. 18)

A small number of women in Kosovo are the owner of a private enterprise, say the companies own manager and representative of women in this sector. According to them, lack of finances, the lack of competent authorities, did the percentage of women involved in the business to be very low. (www.evropaelire.org, n.d.)
The number of Albanian women who are in business continues to be low. There are many obstacles, financial resources are limited, there is discrimination and family role in the launch and development conditions of a business (www.monitori.al).

Data "Women, Business and the Law 2014" of the World Bank in 2013, which evaluates the differences before the law between men and women in the following categories: accessing institutions, using property, getting a job, providing incentives for job , history of good borrowing from going to court, and the protection of women from violence, found that of the 143 countries that were part of the study, including Kosovo, conducted no gender difference in legal terms in general, the greater the gender equality is the greater number of women-owned businesses. However, this conclusion seems unfounded in the case of Kosovo. Since 2012, Business Registration Agency within the Ministry of Trade and Industry has collected data about ownership of businesses that are classified by sex, and reports a $11 \%$ percentage of women-owned businesses. This percentage is much lower compared with the regional average of $36 \%$. Almost all womenowned businesses (99\%) are micro-enterprises, which means that operating profit lower, with fewer workers and lower capitalization (www.womensnetwork.org).

\section{The lack of women in leadership positions}

The apparent lack of women in leadership positions in business and politics is the key obstacle to Kosovo's progress. In general, the reasons that may contribute to the low number of female leaders in the private sector involved "low percentage of women employed, the great burden of domestic responsibilities, the lack of mechanisms for proper evaluation of performance and femradim employees in the private sector, social prejudice against women in senior positions, practices that are likely to be discriminatory, and a lack of role models.

Kosovar women comprise only $0.3 \%$ of top managers in private companies, this percentage among the lowest in Europe and Central Asia, where women make up on average $20 \%$ of managers of companies. A study of KCC in 2012 of women in decision-making positions in the public and private sectors has found that of 71 private companies (mainly small and medium enterprises (SMEs)), representing four sectors 
(ICT, tourism, agriculture and finances), women were believed only an average of $4.2 \%$ of decision-making positions. Moreover, in three important public enterprises, the Post and Telecom of Kosovo (PTK), Kosovo Energy Corporation (KEK) and the Airport of Prishtina, the percentage of women in decisionmaking positions was $20 \%, 11 \%$ and $9 \% .11$ This lack not only provides women "less direct experience in managing businesses compared with men, but also hinder the chances of women to open their business. (www.womensnetwork.org, n.d.)

\section{Participation of the workforce by age and gender}

The Constitution guarantees equal treatment of men and women before the law. Men and women have equal rights to property and inheritance. There are no laws that restrict the industries in which women can work. While Kosovo has a comprehensive legal framework and several mechanisms for the advancement of gender equality, including the Law on Gender Equality of 2004 which was amended in 2015, implementation of the legal framework continues to be challenging. Participation in the labor force, Kosovo has one of the lowest rates of female participation in the workforce to a total of 21.4 percent. According to the Statistics Agency of Kosovo (2015), the share of women aged 15 to 64 in employment is 21.4 percent compared to 61.8 percent for men, which is below the EU average (59.6 percent for women and 70.1 percent for men). The unemployment rate is particularly high among young people, which is of particular concern, considering that Kosovo has the youngest population in Europe. Kosovo's labor market shows signs of vertical and horizontal segregation. Women are overrepresented in administrative positions and by BEEP Survey 2015, only 4 percent of women advance to managerial positions. Women are more likely to have careers and supervisory roles in the public sector than in private companies, 79 percent of all women working in government institutions supervisory or state-owned enterprise. Appellate Labour Statistics Agency of Kosovo (2013) women are under-represented in the energy, construction and transport. In Kosovo, education contributes to gender segregation in the labor market, because female students tend to choose the branch of education, philology, medicine and philosophy while male students make up almost two thirds of all students in the branches of the economy, construction, architecture and computer engineering. (Strategji për Kosovën, 2016, p. 66)

\section{Employment of women in relation to men by age group}

The employment rate in the age group was highest among persons aged between 45-54 years (36.0\%) and lowest among youth (15-24 years) $(8.4 \%)$.

The employment rate for women ages 25-44 ranges from $16.8 \%$ in the age group 25-34 years where falling $1.8 \%$ in the age group $35-44$ years $(15.0 \%)$. While women employed at the young age group (15-24 years old) were only $4.1 \%$ while the older age group (55-64 years) was $10.6 \%$.

Males (Table 7.1), the employment rate was the highest for the age group 35 to 54 years $(58 \%)$, and lowest for youth (12.0\%) (www.atk-rks.gov).

Table 2. The number of employees and employment rates by gender and age

\begin{tabular}{|c|c|c|c|}
\hline Kosovo & Male & Female & Total \\
\hline \multicolumn{4}{|c|}{ EMPLOYMENT (IN THOUSANDS) } \\
\hline $15-24$ & 21.7 & 6.9 & 28.6 \\
\hline $25-34$ & 55.8 & 20.4 & 76.2 \\
\hline $35-44$ & 64.0 & 18.0 & 82.0 \\
\hline $45-54$ & 54.5 & 18.2 & 72.7 \\
\hline $55-64$ & 33.0 & 8.1 & 41.1 \\
\hline $15-64$ & 229.1 & 71.6 & 300.7 \\
\hline \multicolumn{4}{|c|}{ Employment to population ratio (\%) } \\
\hline $15-24$ & 12.0 & 4.3 & 8.4 \\
\hline $25-34$ & 42.1 & 16.8 & 30.0 \\
\hline $35-44$ & 57.9 & 15.0 & 35.5 \\
\hline $45-54$ & 56.8 & 17.1 & 36.0 \\
\hline $55-64$ & 44.9 & 10.6 & 27.4 \\
\hline $15-64$ & 38.6 & 12.2 & 25.5 \\
\hline
\end{tabular}




\section{The participation of women in leadership Business}

"Gender differences in opportunity identification have been linked to differences in human capital variables including education and work experience, with men documented to leverage significantly higher levels of prior industry or entrepreneurial experience as well as experience in managing employees than women" (Shane, 1993).

Participation of women in entrepreneurship and business formal ownership is also very low compared to regional standards. According to the survey data BEEP 2015, only 11.1 percent of businesses have women among the owners, while the percentage of businesses owned by women fully stands at 7.8 percent, which is among the lowest in the EBRD countries of operation. Similarly, the businesses surveyed, only 7.2 percent of businesses have women in senior management positions (www.ebrd.com).

Although Kosovo there are successful women who run businesses, the numbers are still very low, it is estimated that only about 10 percent of businesses are owned by women.

However, the unemployment rate among women is alarming, only 12.5 per cent is the rate of employment among working-age women. Based on recent statistics 14 percent of businesses on behalf of women. 95 percent of them are small and micro businesses in which employees work 1-10.

Business women consider and identify the main obstacles to women's involvement in the economy following obstacles (www.gratebiznes.com):

- The educational level of women

- Lack of experience of women in business

- Lack of women's access to information and finance

- Lack of institutional support, including family, traditions and mentality.

- as well as other social factors and environmental.

\section{Conclusions and recommendations}

Gender structure of the founders shows that the proportion of women and men has become a rise of 93.1.0\% decrease over the years the owners of companies in the small and medium enterprises are male, while only $6.9 \%$ are women, compared with research done in 2005 it was $93.1 .0 \%$ of owners and only $2 \%$ were female.

The level of education of heads of enterprises continues to be low. Monitoring the various trainings in the last years is a very important element to assess compliance with the professional knowledge and application of modern methods.

According to the Business Registration Agency of the Ministry of Trade and Industry, 2012, collected data about the ownership of businesses that are classified by sex, and reports a $11 \%$ percentage of womenowned businesses. This percentage is much lower compared with the regional average of $36 \%$.

The employment rate in the age group was highest among persons aged between $45-54$ years $(36.0 \%)$ and lowest among youth (15-24 years) (8.4\%).

According to the SME Report for Kosev 2014 only $13 \%$ of SMEs are owned by women and another $3 \%$ are co-owned by women. So, the remaining $84 \%$ of SMEs are owned by men.

The main obstacles to the inclusion of women in business are: educational level of women, women's lack of experience in business, women lack access to information and finance Lack of institutional support, etc.

\section{Recommendations}

Organizing an awareness campaign for empowerment of women in the construction and development of SMEs.

It should be organized and training on the importance of operational and strategic planning of economic activity for longer periods of time, which will result in positive effects for the continuation of existing business.

Creating policies to stimulate the financial benefits for those who have the ambition to develop the business, being in tune with the enterprise business plan Improving the ease of closing businesses. The importance of closing business facilitation Contempt often. It is extremely important to undertake the initiative in this area to ensure that honest entrepreneurs can start off their businesses since they have failed. 


\section{References}

1. Retrieved from www.evropaelire.org: http://www.evropaelire.org/a/2288868.html

2. Retrieved from www.monitor.al: http://www.monitor.al/femrat-pengesa-teshumta-ne-biznes-2/

3. Retrieved from www.womensnetwork.org http://www.womensnetwork.org/documents/2 0140611153950100.pdf

4. Retrieved from zeri.info: http://zeri.info/ekonomia/54246/pak-biznesedrejtohen-nga-grate

5. Retrieved from gratenebiznes.com: http://gratenebiznes.com/sq/ (2014).

6. Retrieved from www.womensnetwork.org: http://www.womensnetwork.org/documents/2 0140611153950100.pdf

7. (1985). Sources of Conflict between Work and Family Roles. Greenhaus, J. H., \& Beutell, N. J.

8. (2016). Retrieved from ask.rks-gov.net: http://ask.rks-gov.net/media/2477/afp-tm12016-shqip.pdf

9. (2016). Retrieved from www.ebrd.com: http://www.ebrd.com/documents/strategy and-policy-coordination/draft-kosovostrategy-albanian.pdf

10. Hulumtimi i 600 Ndërmarrjeve të Vogëla dhe të Mesme. ( 2005). Prishtinë: Ministria e Tregëtisë dhe Industrisë Raport.

11. Hulumtimi i 800 Ndërmarrjeve të Vogëla dhe të Mesme. (2011). Prishtinë: Ministria e Tregëtisë dhe Industrisë Raport.

12. Oberholzner, T. (2014). Report on SMEs in Kosovo. Prishtinë: Austrian Institute for SME Research.

13. Shane. (1992-1993). Noordehaven et.al(2003).

14. Strategji për Kosovën. (2016). BANKA EUROPJANE PËR RINDERIM DHE ZHVILLIM.

15. (2008). The Law on General Elections, Law No. 03/L-073, Article 27, Paragraph 1. The Assembly of the Republic of Kosovo. 